\title{
Power Lamp Device
}

National Cancer Institute

\section{Source}

National Cancer Institute. Power Lamp Device. NCI Thesaurus. Code C50113.

A light designed to indicate the status of a power source or power connection. 